\title{
Analisis Implementasi Triage, Ketepatan Diagnosa Awal Dengan Lama Waktu Rawatan Pasien di RSUD Prof. DR. MA Hanafiah SM Batusangkar
}

\author{
Ardian Amri ${ }^{1}$, Menkher Manjas ${ }^{2}$, Hardisman $^{3}$
}

\begin{abstract}
Abstrak
Keselamatan pasien saat ini menjadi perhatian penting dalam pelayanan kesehatan seperti di rumah sakit. Salah satu upaya untuk meningkatkan pelayanan kesehatan dengan cara menerapkan standar keselamatan pasien dengan melaksanakan sistem triage yang dilakukan di Instalasi Gawat Darurat (IGD). Tujuan: Menganalisis ketepatan triage, ketepatan diagnosa awal dan lamanya waktu rawatan pasien di RSUD Prof. DR. M.A Hanafiah SM Batusangkar. Metode: Penelitian ini menggunakan metode penelitian kombinasi (mixed methods) dengan desain sequential explanatory. Hasil: penelitian didapatkan bahwa pelaksanaan triage di IGD RSUD Prof. DR. M.A Hanafiah SM Batusangkar tidak tepat hasilnya adalah sebesar 6,7\%. Diagnosa tidak tepat yang dilakukan dokter terhadap pasien IGD sebanyak 9,6\%. Sebesar 30,8\% pasien lama rawatannya tidak sesuai dengan Clinical pathway. Tidak ada hubungan yang bermakna antara ketepatan triage dengan lamanya hari rawatan $(0,673)$, dan terdapat hubungan yang bermakna antara ketepatan diagnosa dengan lamanya hari rawatan (0,001). Simpulan: Triase di IGD RSUD Prof. DR. M.A Hanafiah SM Batusangkar sudah dilaksanakan sesuai standar triage Australia. Dokter sudah melakukan tindakan atau diagnosa sesuai Standar Operasional Prosedur (SOP) tetapi masih ada terjadi kesalahan diagnosa dilihat dari adanya perbedaan diagnosa awal dan diagnosa saat pasien pulang. Persepsi pasien terhadap pelayanan IGD adalah merasa kurang puas, karena pasien merasa diabaikan jika jumlah pasien sedang banyak.
\end{abstract}

Kata kunci: ketepatan triage, ketepatan diagnosa, lama waktu rawatan, instalasi gawat darurat

\section{Abstract}

Patient safety is now an important concern in health services such as in hospitals. One of the efforts to improve health services is by implementing patient safety standards by implementing a triage system conducted at the Accident and Emergency Departement. Objectives: To analized the accuracy of triage, the accuracy of the initial diagnosis and the length of time the patient is treated at the Regional Hospital Prof. DR. M.A Hanafiah SM Batusangkar. Methods: This study used a mixed methods with a sequential explanatory design. Results: The implementation of triage at the emergency room at the Regional Hospital Prof. DR. M.A Hanafiah SM Batusangkar is not right the result is $6.7 \%$. Inappropriate diagnosis by doctors of Accident and Emergency Departement patients is $9.6 \%$. As many as $30.8 \%$ of patients treated for a long time did not comply with the Clinical Pathway. Conclusions: There was no significant relationship between the accuracy of triage and the length of day of treatment (0.673), and there was a significant relationship between the accuracy of the diagnosis and the length of treatment day (0.001). The conclusion is triage at the emergency room at Regional Hospital Prof. DR. M.A Hanafiah SM Batusangkar has been carried out according to Australian triage standards. The doctor has taken action or diagnosis according to the Standard Operating Procedure $(S O P)$ but there is still a diagnostic error seen from the existence of differences in the initial diagnosis and diagnosis when the patient returns home. The patient's perception of Accident and Emergency Departement services is still less satisfied, because the patient is still ignored if the patient is in very many conditions.

Keywords: triage accuracy, diagnose accuracy, treatment time, accident and emergency departement 
Affiliasi penulis: 1. RSUD Prof. DR. M.A. Hanafiah SM Batusangkar 2. Bagian Bedah Fakultas Kedokteran Universitas Andalas Padang (FK Unand) 3. Bagian IImu Kesehatan Masyarakat FK Unand. Korespondensi: Menkher Manjas, Email: menkherm@yahoo.com Telp : 08129291831

\section{PENDAHULUAN}

Instalasi Gawat Darurat (IGD) adalah suatu unit pelayanan di rumah sakit yang memberikan pelayanan terhadap masyarakat yang mengalami penyakit akut maupun yang mengalami trauma sesuai dengan standar yang ditetapkan. Gawat darurat merupakan keadaan dimana pasien memerlukan pemeriksaan medis segera dan apabila tidak dilakukan pemeriksaan akan berakibat fatal bagi pasien tersebut. $^{1}$

Pasien yang datang ke IGD akan mengalami proses triage (pemilihan). Triage diartikan sebagai proses memilah pasien menurut tingkat keparahannya. ${ }^{2}$ Pasien akan mendapatkan pelayanan sesuai kondisi dan tingkat kegawatan. Pada saat atau setelah proses triage, maka keluarga pasien/ pengantar secara bersamaan diarahkan untuk mendaftar identitas pasien, kemudian pasien akan dilayani oleh dokter jaga dan perawat. Diagnosa dan terapi, dokter jaga akan melengkapi pemeriksaan fisik dan penunjang (laboratorium, radiologi). Dokter jaga IGD juga didukung oleh dokter spesialis yang lengkap dan siap on call 24 jam. Setelah mendapat pelayanan di IGD, pasien dapat dirawat, pulang atau bahkan ada yang meninggal. Diakhiri proses pelayanan, pasien dan keluarga akan menyelesaikan administrasi, sedangkan untuk pasien dirawat, maka penyelesaian administrasi pada saat pasien pulang dirawat. ${ }^{3}$

Keselamatan pasien saat ini menjadi perhatian penting dalam pelayanan kesehatan seperti di rumah sakit. Salah satu upaya untuk meningkatkan pelayanan kesehatan dengan cara menerapkan standar keselamatan pasien dengan melaksanakan sistem triage yang dilakukan di IGD. Metode triage yang biasa digunakan adalah Simple Triage And Rapid Treatment (START). Metode START digunakan untuk pertolongan pertama pada pasien dengan lama waktu penggolongan 30 detik atau kurang berdasarkan tiga pemeriksaan primer seperti respirasi, perfusi (mengecek nadi radialis) dan status mental. $^{1}$

Kemampuan dokter dalam melakukan triage sangat berpengaruh terhadap tingkat keberhasilan pertolongan pada saat pasien mengalami kegawat daruratan. Ketepatan perawat dalam melaksanakan triage juga dipengaruhi oleh berbagai faktor antara lain pengetahuan perawat tentang triage, motivasi kerja dan beban kerja. Pengetahuan menjadi salah satu faktor yang sangat penting dalam ketepatan pelaksanaan triage. ${ }^{2}$

Berdasarkan studi pendahuluan yang dilakukan pada 6 Maret 2018 di IGD RSUD Prof. DR. M.A Hanafiah SM, jumlah perawat ada 19 perawat dan 5 bidan. Sistem triage yang digunakan adalah START sistem. Setiap pasien yang datang akan dilakukan triage oleh perawat ataupun bidan yang berjaga, tidak ada petugas triage khusus karena semua perawat dan bidan yang berjaga berwenang melakukan triage. Pasien akan masuk ruang triage dan akan dilakukan triage sesuai dengan kegawatan pasien.

Penandaan triage dilakukan dengan melihat warna pada lembar observasi ketepatan triage yang digunakan. Setelah dilakukan triage pasien akan ditempatkan sesuai dengan golongan triagenya. Uptriage dilakukan ketika terjadi kondisi pasien yang tiba-tiba memburuk ataupun ketika terjadi keraguraguan dalam menentukan tingkat kegawatan (triage). Dalam melakukan triage pernah terjadi kesalahan terutama pada kunjungan pasien banyak, namun kesalahan tersebut langsung dilakukan uptriage. ${ }^{2}$

\section{METODE}

Penelitian ini menggunakan metode kombinasi (mixed methods) dengan desain sequential explanatory yaitu metode penelitian yang menggabungkan kuantitatif dan kualitatif secara berurutan. Metode ini menggunakan metode kuantitatif pada tahap pertama dengan pendekatan cross sectional dan pada tahap kedua menggunakan metode kualitatif untuk mendukung hasil penelitian kuantitatif yang dilakukan pada tahap pertama. ${ }^{4}$ 


\section{HASIL}

\section{Analisis Univariat}

Analisis univariat merupakan analisis yang digunakan untuk melihat distribusi frekuensi atau gambaran dari masing-masing variabel penelitian.

\section{a. Ketepatan Triage}

Tabel 1. Ketepatan triage yang dilaksanakan di IGD RSUD Prof.DR.M.A Hanafiah, SM Batusangkar

\begin{tabular}{lcc}
\hline \multicolumn{1}{c}{ Karakteristik Triage } & $\mathbf{f}$ & $\%$ \\
\hline TriageTepat & 87 & 82.1 \\
TriageTidak Tepat & 19 & 17.9 \\
Total & 106 & 100 \\
\hline
\end{tabular}

\section{b. Ketepatan Diagnosa}

Tabel 2. Ketepatan diagnosa yang dilaksanakan di IGD RSUD Prof.DR.M.A Hanafiah, SM Batusangkar

\begin{tabular}{lcc}
\hline Karakteristik Ketepatan Diagnosa & $\mathbf{f}$ & $\%$ \\
\hline Diagnosa Tepat & 97 & 91.5 \\
Diagnosa Tidak Tepat & 9 & 8.5 \\
Total & 106 & 100 \\
\hline
\end{tabular}

C. Lamanya Hari Rawatan

Tabel 3. Ketepatan lamanya hari rawatan yang dilaksanakan di IGD RSUD Prof.DR.M.A Hanafiah, SM Batusangkar

\begin{tabular}{lcc}
\hline Karakteristik Lamanya Hari Rawatan & $\mathbf{f}$ & $\%$ \\
\hline Sesuai panduan praktek klinis & 73 & 68.9 \\
Tidak sesuai panduan praktek klinis & 33 & 31.1 \\
Total & 106 & 100 \\
\hline
\end{tabular}

\section{Analisis Bivariat}

Analisis bivariat dilakukan untuk mengetahui hubungan antara variabel Independen (ketepatan triage, ketepatan diagnosa) dengan variabel dependen (lamanya hari rawatan). Hasil analisis bivariat penelitian yaitu:
Tabel 4. Hubungan ketepatan triage dengan lama rawatan

\begin{tabular}{|c|c|c|c|c|c|c|c|}
\hline \multirow{7}{*}{$\begin{array}{c}\text { Ketepatan } \\
\text { Triage }\end{array}$} & \multicolumn{4}{|c|}{ Lamanya Hari Rawatan } & & & \\
\hline & \multirow{2}{*}{\multicolumn{2}{|c|}{$\begin{array}{c}\text { Sesuai } \\
\text { Panduan }\end{array}$}} & \multicolumn{2}{|c|}{ Tidak } & \multirow{3}{*}{\multicolumn{2}{|c|}{ Total }} & \multirow{5}{*}{$\mathbf{p}$} \\
\hline & & & & suai & & & \\
\hline & \multirow{2}{*}{\multicolumn{2}{|c|}{$\begin{array}{c}\text { Praktek } \\
\text { Klinis }\end{array}$}} & \multirow{3}{*}{\multicolumn{2}{|c|}{$\begin{array}{c}\text { Panduan } \\
\text { Praktek } \\
\text { Klinis }\end{array}$}} & & & \\
\hline & & & & & \multirow[b]{3}{*}{ f } & \multirow[b]{3}{*}{$\%$} & \\
\hline & & & & & & & \\
\hline & $f$ & $\%$ & $f$ & $\%$ & & & \multirow{3}{*}{1.000} \\
\hline Tepat & 60 & 69.0 & 27 & 31.0 & 87 & 100 & \\
\hline Tidak tepat & 13 & 68.4 & 6 & 31.6 & 19 & 100 & \\
\hline
\end{tabular}

Diketahui persentase lama rawatan sesuai dengan Panduan Praktek Klinis dengan Triage tepat lebih tinggi (69,0\%) dibandingkan lamanya hari rawatan sesuai Panduan Praktek Klinis dengan Triage tidak tepat $(68.4 \%)$

Tabel 5. Hubungan ketepatan diagnosa dengan lama rawatan

\begin{tabular}{|c|c|c|c|c|c|c|c|}
\hline \multirow{7}{*}{$\begin{array}{l}\text { Ketepatan } \\
\text { Diagnosa }\end{array}$} & \multicolumn{4}{|c|}{ Lamanya Hari Rawatan } & & & \\
\hline & \multirow{2}{*}{\multicolumn{2}{|c|}{$\begin{array}{c}\text { Sesuai } \\
\text { Panduan }\end{array}$}} & \multicolumn{2}{|c|}{ Tidak } & & & \\
\hline & & & & suai & & & \\
\hline & \multicolumn{2}{|c|}{ Praktek } & \multicolumn{2}{|c|}{ Panduan } & \multicolumn{2}{|c|}{ Total } & $\mathrm{p}$ \\
\hline & \multicolumn{2}{|c|}{ Klinis } & \multirow{2}{*}{\multicolumn{2}{|c|}{$\begin{array}{l}\text { Praktek } \\
\text { Klinis }\end{array}$}} & \multirow[b]{3}{*}{$f$} & \multirow[b]{3}{*}{$\%$} & \\
\hline & & & & & & & \\
\hline & f & $\%$ & f & $\%$ & & & \multirow[b]{2}{*}{1.00} \\
\hline Tepat & 60 & 69.0 & 27 & 31.0 & 87 & 100 & \\
\hline Tidak tepat & 13 & 68.4 & 6 & 31.6 & 19 & 100 & 0 \\
\hline
\end{tabular}

Diketahui persentase lama hari rawatan sesuai dengan Panduan praktek klinis dengan diagnose tepat lebih tinggi (74.2\%) dibandingkan lamanya hari rawatan sesuai Panduan praktek klinis denga diagnosa tidak tepat (11.1\%).

1. Ketepatan triage

Berdasarkan hasil wawancara mendalam, Focus Group Discussion (FGD) dan observasi disajikan dalam matrik triangulasi pada Tabel 6 berikut ini: 
Tabel 6. Matrik triangulasi metode tentang ketepatan pelaksanaan triage di IGD RSUD Prof. DR. M.A Hanafiah SM Batusangkar

\begin{tabular}{lllll}
\hline \multicolumn{1}{c}{ Topik } & $\begin{array}{l}\text { Wawancara } \\
\text { mendalam }\end{array}$ & FGD & Observasi & $\begin{array}{c}\text { Analisis } \\
\text { Triangulasi }\end{array}$ \\
\hline Pelaksanaan & Pelaksanaan & Pasien & Triage & Triage di \\
ketepatan & triage sudah & diterima & sudah & IGD RSUD \\
triage & dilaksanakan & IGD dan & dijalankan & Prof. DR. \\
& sesuai & langsung & di IGD & M.A \\
& standar & dtangani & RSUD Prof. & Hanafiah, \\
& Australia & sesuai & DR. M.A & SM \\
& dengan & tingkat & Hanafiah & Batusang \\
& membedakan & kegawatan & SM & kar sudah \\
& pasien & nya & Batusang & dilaksana \\
& kepada triage & & kar. & kan \\
& merah, & & & \\
& kuning, hijau & & & \\
& dan hitam. & & & \\
\hline
\end{tabular}

\section{Ketepatan diagnosa}

Berdasarkan hasil wawancara mendalam dan telaah dokumen disajikan dalam matrik triangulasi pada Tabel 7 berikut ini:

Tabel 7. Matrik triangulasi metode tentang ketepatan diagnosa di IGD RSUD Prof. DR. M.A Hanafiah SM Batusangkar

\begin{tabular}{llll}
\hline Topik & $\begin{array}{l}\text { Wawancara } \\
\text { mendalam }\end{array}$ & Observasi & \multicolumn{1}{c}{$\begin{array}{c}\text { Anailisis } \\
\text { Triangulasi }\end{array}$} \\
\hline Ketepatan & Diagnosa & Dalam dokumen & Dokter sudah \\
diagnose & yang & ditemukan masih & melakukan \\
& dilakukan & ada diagnosa & tindakan atau \\
& kepada & pasien awal dan & diagnosa sesuai \\
& pasien sudah & pasien pulang & soP tetapi masih \\
tepat. & yang berbeda. & ada terjadi \\
& & & kesalahan \\
& & & diagnosa dilihat \\
& & & dari adanya \\
& & perbedaan \\
& & diagnosa awal dan \\
& & diagnosa pada \\
& & & saat pasien \\
& & & pulang. \\
\hline
\end{tabular}

\section{Persepsi pasien}

Berdasarkan hasil wawancara mendalam dan Focus Group Discussion (FGD) disajikan dalam matrik triangulasi pada Tabel 8 berikut ini:
Tabel 8. Matrik triangulasi metode tentang persepsi pasien di IGD RSUD Prof. DR. M.A Hanafiah SM Batusangkar

\begin{tabular}{llll}
\hline Topik & $\begin{array}{l}\text { Wawancara } \\
\text { mendalam }\end{array}$ & \multicolumn{1}{c}{ FGD } & \multicolumn{1}{c}{$\begin{array}{c}\text { Anailisis } \\
\text { Triangulasi }\end{array}$} \\
\hline Persepsi & Pasien & Pelayanan lambat & Perawat melakukan \\
pasien & mengeluhkan & karena perawat & tindakan terhadap \\
& pelayanan & harus & pasien berdasarkan \\
& perawat yang & mendahulukan & tindakan \\
& lambat dan & pasien yang gawat & kegawatannya, \\
& tidak ramah & dan karena kondisi & sehingga pasien \\
& & pasien sering & yang tidak gawat \\
& ramai & ditunda sebentar, \\
& & & dan pelayanan yang \\
& & & lama disebabkan \\
& & & jumlah pasien yang \\
& & & banyak \\
\hline
\end{tabular}

\section{PEMBAHASAN}

\section{A. Penelitian Kuantitatif}

Analisis Univariat

\section{a. Ketepatan triage}

Berdasarkan hasil penelitian dapat diketahui jika sebagian besar triage sudah tepat, hanya sebagian sebagian kecil saja yang tidak tepat. Hal ini menunjukkan jika selama ini perawat sudah memberikan pelayanan sesuai dengan triage yang ditetapkan. Perawat IGD sudah bisa memilah atau menggolongkan semua pasien yang datang ke IGD dan menetapkan prioritas penanganannya.

Sistem triage yang menjadi acuan perawat adalah Simple Triage And Rapid Treatment (START), sistem ini ideal untuk incident korban massal tetapi tidak terjadi functional collapse rumah sakit. Prinsip dari START adalah untuk mengatasi ancaman nyawa, jalan nafas yang tersumbat dan perdaharan masif arteri. Pelayanan triage dengan sistem START di IGD RSUD Prof. DR. M.A Hanafiah SM Batusangkar ini mengklasifikasikan pasien dalam kelompok terapi hijau yaitu pasien sadar dan dapat jalan dipisahkan dari pasien lain, walking wounded dan pasien histeris, triase kuning yaitu semua pasien yang tidak termasuk golongan merah dan hijau, triage merah yaitu semua pasien dengan gangguan airway, breathing, circulation 
disability and exposure termasuk pasien pasien yang bernafas setelah airway dibebaskan, kemudian triase hitam yaitu pasien meninggal dunia.

Prinsip triage diartikan sebagai suatu tindakan pengelompokkan penderita berdasarkan beratnya cidera yang diprioritaskan, triage harus dilakukan segera dan cepat. Setiap perawat harus memiliki kemampuan untuk menilai dan merespon dengan cepat kemungkinan yang dapat menyelamatkan nyawa pasien dari kondisi sakit atau cedera yang mengancam nyawa. Jumlah pasien, keterampilan perawat, ketersediaan peralatan dan sumber daya dapat menentukan setting prioritas.

Hasil yang berbeda didapatkan oleh Khairina et al (2018) dalam penelitiannya yang menyatakan jika pendidikan bukan menjadi faktor penentu dalam pengambilan keputusan perawat melaksanakan triage, justru faktor yang dominan memepengaruhi ketetepatan perawat dalam pengambilan keputusan melaksanakan triage adalah faktor pengetahuan. ${ }^{5}$

\section{b. Ketepatan diagnosa}

Berdasarkan hasil yang didapat jika, pasien IGD sebagian besar sudah di diagnosa secara tepat, sedangkan diagnosa yang tidak tepat hanya sebagian kecil. hal ini menunjukkan jika dokter sudah tepat dalam menegakkan atau mengidentifikasi mengenai suatu jenis penyakit atau masalah kesehatan yang diderita atau dialami oleh seorang pasien atau masyarakat, hasil diagnosa yang dilakukan oleh dokter adalah diagnosa penyakit.

Ketidaktepatan penilaian triage memiliki resiko menurunnya angka keselamatan pasien dan kualitas dari layanan kesehatan. Penilaian yang dikategorikan ke undertriage memiliki dampak langsung ke waktu tunggu pasien dan penurunan angka keselamatan pasien. Hal ini terjadi disebabkan karena penurunan penilaian skala triage daripada yang seharusnya akan memperpanjang waktu penanganan yang seharusnya diterima oleh pasien tersebut sesuai dengan kondisi klinisnya. Indikator lama waktu tunggu pasien di instalasi gawat. ${ }^{5}$

Ketepatan melakukan diagnosa menjadi langkah awal dalam sebuah proses pengobatan karena ketepatan melakukan diagnosis maka akan mempengaruhi tindakan yang akan dilakukan selanjutnya. Diagnosa juga meliputi penentuan kebutuhan pasien untuk perawatan seperti dukungan, bimbingan, jaminan, pendidikan, pelatihan, dan perawatan lainnya yang memfasilitasi kemampuan pasien untuk mencari perawatan.

c. Lamanya hari rawatan

Berdasarkan hasil diketahui jika lebih dari separuh lebih pasien lama hari rawatannya sudah sesuai dengan Clinical Pathway, sedangkan kurang dari separuh pasien lama rawatannya tidak sesuai dengan Clinical Pathway. Lama rawat atau lama hari rawat atau Length of Stay (LOS) adalah suatu ukuran berapa hari lamanya seorang pasien dirawat inap pada suatu periode perawatan. Satuan lama hari rawat adalah hari. 30\% pasien yang lama rawatannya tidak sesuai dengan Clinical Pathway karena masih ada perbedaan diagnosis yang dilakukan dokter IGD terhadap pasien saat datang dengan diagnosis pasien pulang.

Di Indonesia Standar Pelayanan Minimal pelayanan IGD dilakukan selama 24 jam penuh, 7 hari terhadap kasus gawat darurat, resusitasi dan stabilisasi (life saving). Waktu tunggu pasien saat kedatangan pasien < 5 menit. Pada kondisi kepadatan pasien manajemen IGD dapat menerapkan lama rawat $<6-8$ jam. $^{6}$

Analisis Bivariat

a. Hubungan ketepatan triage dengan lamanya hari rawatan

Ketepatan perawat dalam melakukan triage disini artinya adalah ketepatan perawat dalam menangani dan memilah pasien. Salah satu peran dan fungsi perawat gawat darurat adalah melakukan triage, mengkaji dan menetapkan prioritas dalam spektrum lebih luas terhadap kondisi klinis pada berbagai keadaan yang bersifat mendadak mulai dari ancaman nyawa sampai kondisi kronis. ${ }^{7}$

Analisis bivariat menunjukkan jika persentase triage tepat yang sesuai Clinical Pathway lebih tinggi dibandingkan dengan triage tidak tepat tidak sesuai Clinical Pathway, yaitu $70,1 \%$ berbanding 29\%. Persentase ketepatan diagnosa yang tepat sesuai Clinical Pathway dibandingkan diagnosa tidak tepat sesuai Clinical Pathway, yaitu $75,5 \%$ berbanding $10 \%$. 
Hasil uji statistik diperoleh nilai $p<0,05$. Dapat disimpulkan bahwa ada hubungan yang bermakna antara ketepatan diagnosa dengan lamanya hari rawatan.

\section{b. Hubungan ketepatan diagnosa dengan lamanya hari rawatan}

Ketepatan merupakan seberapa jauh perilaku seseorang dalam hal penggunaan obat, mengikuti diet atau mengubah gaya hidup sesuai dengan nasehat medis atau saran kesehatan sehingga tidak terjadi hal yang membahayakan hasil terapi pasien. ${ }^{8}$ Ketepatan diagnosa dalam penelitian ini adalah diagnosa dikatakan tepat jika diagnosa awal pasien masuk sama dengan diagnosa pasien saat pulang. Jika diagnosa tepat maka lama hari rawatan pasien juga sesuai dengan Clinical Pathway, tetapi jika diagnosa tidak tepat maka tidak akan sesuai dengan Clinical Pathway.

Hasil uji statistik bivariat yang dilakukan didapatkan hasil persentase ketepatan diagnosa yang tepat sesuai Clinical Pathway dibandingkan diagnosa tidak tepat sesuai Clinical Pathway, yaitu 75,5\% berbanding $10 \%$. Hasil uji statistik diperoleh nilai $p<$ 0,05 . Dapat disimpulkan bahwa ada hubungan yang bermakna antara ketepatan diagnosa dengan lamanya hari rawatan.

\section{B. Penelitian Kualitatif}

\section{Ketepatan triage}

Sistem triage gawat darurat medis digunakan untuk menentukan pasien maan yang harus ditangani lebih dahulu dibandingkan dengan pasien lainnya. Konsep awal triage gawatdarurat adalah membagi pasien menjadi 3 kategori yaitu immediate, urgent dan non urgent. Sistem triage medis memilah pasien berdasarkan kondisi saat masuk ruang perawatan dan memberikan kode warna untuk pasien mulai dari merah yang diberikan kepada pasien yang jika tidak diberikan penanganan dengan cepat maka pasien akan meninggal, dengan syarat pasien tersebut masih memiliki kemungkinan untuk hidup.

Pelaksanaan triage sangat penting dilaksanakan dalam kondisi kegawatdaruratan, sehingga faktor yang berhubungan dengan pelaksanaan triage perlu diidentifikasi, melalui pelaksanaan triage, kepuasan pasien dirumah sakit akan dapat tercapai serta kematian dan kecacatan pada kasus kegawatdaruratan dapat diminimalkan.

Triage kuning diberikan kepada pasien yang memerlukan perawatan segera, namun masih dapat ditunda karena ia masih dalam kondisi stabil. Pasien dengan kondisi kuning masih memerlukan perawatan di rumah sakit dan pada kondisi normal akan segera ditangani. Triage hijau diberikan kepada pasien yang memerlukan perawatan tetapi masih dapat ditunda, biasanya pasien cedera yang masih sadar dan bisa berjalan masuk dalam kategori ini. Ketika pasien gawat lain sudah selesai ditangani, maka pasien dengan kode warna hijau akan ditangani. Triage hitam diberikan kepada pasien yang setelah diperiksa tidak menunjukkan tanda-tanda kehidupan.

Berdasarkan hasil penelitian triage yang diterapkan di RSUD Prof. DR. M.A Hanafiah SM Batusangkar adalah triage skala Australia, yaitu penghitungan waktu dimulai sejak pasien pertama kali tiba di UGD, pemeriksaan tanda vital dilakukan hanya jika perawat akan mengambil keputusan tingkat kedaruratan triage disamping melakukan pemeriksaan kegawatan pasien secara menyeluruh. Pelaksananaan triage di RSUD Prof. DR. M.A Hanafiah SM Batusangkar sudah dijalankan sesuai standar, hal ini didukung oleh hasil penelitian kuantitatif melalui uji statistik univariat jika lebih dari 93\% triage yang dilakukan perawat sudah tepat. Pelaksanaan triage di IGD dilakukan oleh perawat.

Perawat merupakan seseorang yang telah dipersiapkan merawat dan menyembuhkan orang yang sakit meliputi usaha rehabilitasi, pencegahan penyakit yang dilaksanakan sendiri dibawah pengawasan dokter. ${ }^{9}$ Di ruangan IGD perawat adalah sumber daya manusia dirumah sakit yang harus mampu memberikan pelayanan atau tindakan keperwatan secara profesional sehingga tingkat kepercayaan pasien dan keluarga terus meningkat terhadap perawat. ${ }^{10}$

Keterampilan triage merupakan kemampuan seseorang menerapkan pengetahuan kedalam bentuk tindakan. Di Instalasi Gawat Darurat (IGD) pengetahuan dan keterampilan perawat sangat dibutuhkan, terutama dalam pengambilan keputusan klinis dimana keterampilan penting bagi perawat 
dalam penilaian awal. Perawat harus mampu memprioritaskan perawatan pasien atas dasar pengambilan keputusan yang tepat, untuk mendukung hal tersebut diperlukan pengetahuan dan keterampilan khusus dalam pemisahan jenis dan kegawatan pasien dalam triage, sehingga dalam penanganan pasien bisa lebih optimal dan terarah. Pemisahan yang dimaksud adalah triage. ${ }^{11}$

Pelatihan dapat meningkatkan keterampilan petugas kesehatan dalam melaksanakan tugasnya. ${ }^{12}$ Dalam keterampilan anamnesa pasien, perawat memfokuskan kepada keluhan utama pasien, kapan masalah itu timbul dan tindakan yang sudah dilakukan sebelum pasien datang ke IGD. Pertimbangan lain dalam keterampilan pengambilan keputusan di triage adalah setiap gejala yang cendrung berulang dan intensitasnya meningkat, setiap gejala yang disertai perubahan pasti lainnya, kemunduran yang progresif, usia yang sangat muda atau sangat tua, dan pasien tidak dapat menjelaskan sumber masalah.

Penelitian lain di dapatkan hasil bahwa sebanyak 15 orang (100\%) menunjukkan perawat yang mendapatkan pelatihan BCTLS dan PPGD memiliki sikap dan keterampilan yang baik dalam menerapkan tindakan triage sesuai dengan protap atau ketentuan yang berlaku di IGD. ${ }^{13}$

Hal ini sudah diatasi oleh pihak manajemen dengan menganggarkan biaya pelatihan perawat IGD di tahun 2019 untuk memberikan kesempatan kepada perawat tersebut meningkatkan kompetensinya melalui pelatihan, sehingga indikator SPM perawat yang memiliki sertifikat dapat mencapai target $100 \%$ dan pelayanan IGD di RSUD Prof. DR. M.A Hanafiah SM Batusangkar.

\section{Ketepatan diagnosa}

Dalam proses penetapan diagnosa pasien, dokter melakukan beberapa tahapan yaitu : proffiling yang merupakan proses paling awal yang dilakukan oleh dokter untuk mengerucutkan diagnosis yaitu dengan mengumpulkan identitas pasien. Tahap kedua yaitu melakukan anamnesa dan juga merupakan langkah awal mengumpulkan informasi, dimana dokter bertanya apa saja keluhan pasien dan menggali lebih lanjut pertanyaan yang terarah untuk mengerucutkan diagnosa, misalnya keluhan pasien kapan dirasakan, bagaiman terjadinya bagaimana keluhan diatasi, apakah ada keluhan lain dan lain-lain. Ada dua tipe anamnesa yang dilakukan dokter untuk mendiagnosis penyakit yaitu auto anamnesis yaitu tanya jawab langsung kepada pasien dan allo anamnesis yaitu tanya jawab yang dilakukan dengan keluarga pasien, untuk keberhasilan diagnosis penyakit adalah dokter harus menanyakan keluhan utama yang menjadi sebab si pasien berobat atau masuk kerumah sakit.

Tahap ketiga adalah pemeriksaan fisik yang langsung dilakukan kepada pasien, hal-hal yang dilakukan dalam pemeriksaan fisik adalah inspeksi yaitu melihat, mengamati keadaan penderita secara garis besar, palpasi atau perabaa, perkusi atau ketukan serta auskultasi atau mendengarkan dengan alat.

Tahap keempat adalah melakukan pemeriksaan penunjang bila selama pemeriksaan fisik ada hal-hal yang masih meragukan, dokter membutuhkan pemeriksaan lain untuk mengkonfirmasi misalnya radiografi seperti Magneting Resonance Imaging (MRI), Computed Tomography Scan (CT Scan), Ultrasonografi ((USG) atau pemeriksaan laboratorium.

Berdasarkan fakta dilapangan ditemui jika masih ada perbedaan diagnosa antara dokter IGD dengan dokter penanggung jawab pasien. Seharusnya ada persamaan persepsi antara dokter IGD dengan DPJP untuk menghindari terjadinya perbedaan diagnosa pada pesain. Untuk itu diharapkan adanya koordinasi antara dokter IGD dengan DPJP terkait penegakan diagnosa pasien.

\section{Persepsi pasien}

Berdasarkan hasil penelitian terkait persepsi pasien terhadap pelayanan di IGD RSUD Prof. DR. M.A Hanafiah SM Batusangkar diketahui jika masih ada pasien yang masih merasa kurang puas terhadap pelayanan perawat yang dianggap lambat dan mengabaikan pasien, hal ini berpengaruh terhadap penilaian pasien terhadap kualitas pelayanan di IGD, observasi yang dilakukan langsung oleh peneliti juga memperlihatkan adanya pasien yang mengeluh karena belum mendapat pelayanan di IGD, hal tersebut terjadi disaat jumlah pasien meningkat di IGD. Hal ini mestinya menjadi bahan evaluasi bagi 
manajemen Rumah Sakit. Manajemen mestinya bisa mengkaji ulang tentang kebutuhan tenaga perawat di IGD dibandingkan dengan kunjungan pasien, jika jumlah pasien selalu ramai sebaiknya manajemen menambah tenaga perawat di IGD.

Jumlah pasien dapat mempengaruhi pelayanan yang dilakukan oleh perawat atau tenaga medis, jumlah pasien yang banyak, bisa memungkin pelaksanaan triage tidak tepat. Ada hubungan jumlah kunjungan pasien dengan ketepatan pelaksanaan triage di instalasi gawat darurat, pelaksanaan triage yang tepat dapat dilakukan disaat kunjungan pasien tidak banyak dan sebaliknya jika jumlah pasien meningkat maka berkemungkinan menimbulkan pelaksanaan triage yang tidak tepat. ${ }^{14}$

Masyarakat atau pasien melihat pelayanan yang bermutu sebagai suatu pelayanan kesehatan yang dapat memenuhi kebutuhan yang dirasakannya dan diselenggarakan dengan cara yang sopan dan santun, tepat waktu, tanggap dan mampu menyembuhkan keluarganya serta mencegah berkembangnya atau meluasnya penyakit. Persepsi pasien sangat penting karena pasien yang merasa puas akan mematuhipengobatan dan mau datang berobat kembali. ${ }^{15}$

\section{SIMPULAN}

Tidak ada hubungan yang bermakna antara ketepatan triage dengan lamanya hari rawatan, ada hubungan yang bermakna antara ketepatan diagnosa dengan lamanya hari rawatan. Triage di IGD RSUD Prof. DR. M.A Hanafiah SM Batusangkar sudah dilaksanakan sesuai standar triage Australia. Dokter sudah melakukan tindakan atau diagnosa sesuai Standar Operasional Prosedur (SOP) tetapi masih ada terjadi kesalahan diagnosa dilihat dari adanya perbedaan diagnosa awal dan diagnosa pada saat pasien pulang serta persepsi pasien terhadap pelayanan IGD adalah masih merasa kurang puas, karena pasien merasa masih diabaikan jika jumlah pasien sedang banyak.

\section{SARAN}

Pihak manajemen RSUD melalui direktur agar meningkatkan anggaran biaya pelatihan bagi perawat dan dokter di IGD yang belum mendapatkan pelatihan, meningkatkan koordinasi antara dokter IGD dengan dokter penanggung jawab pasien saat melakukan diagnosa terhadap pasien, Dokter penanggung jawab pasien patuh terhadap clinical pathway, mempertimbangkan sebelum melakukan rolling atau perpindahan tugas perawat dari IGD ke ruangan lain dan sebaliknya dan melengkapi sarana penunjang diagnostik di IGD.

\section{UCAPAN TERIMA KASIH}

Terimakasih kepada seluruh pihak yang turut membantu dalam menyelesaikan penelitian ini.

\section{DAFTAR PUSTAKA}

1 Kartikawati ND. Buku ajar dasar dasar keperawatan gawat darurat. Jakarta: Salemba Medika; 2011.hlm.27-34.

2 Zimmerman, Herr. Triage nursing secret. Philadelpia: Elsevier Mosby; 2006.hlm.127-9.

3 Kementerian Kesehatan RI. Standar instalasi gawat darurat di rumah sakit. Jakarta: Kementerian Kesehatan RI; 2009.

4 Sugiyono. Metode penelitian kombinasi. Bandung: Alfabeta; 2016.hlm.59-60.

5 Khairina I, Mallini H. Huriani E. Faktor-faktor yang berhubungan dengan pengambilan keputusan perawat dalam ketepatan triage di kota Padang. Indonesian Journal for Health Sciences. 2018; 2(1):1-7.

6 Kementerian Kesehatan RI. Kepmenkes RI No. 856 tentang Standar Penanganan Pasien Gawat Darurat. Jakarta: Kementerian Kesehatan RI; 2009.

7 Faidah N, Ratnawaty R, Setyoadi. Pengalaman perawat dalam pengambilan keputusan triage di instalasi gawat darurat RSUD RAA Sowondo Pati. Jurnal Keperawatan dan Kesehatan Masyarakat Cendekia Utama. 2013;1(2):93-104.

8 Rantucci MJ. Komunikasi apoteker-pasien. Jakarta: ECG; 2009.hlm.13-4.

9 Departemen Kesehatan RI. Pedoman manajemen sumber daya manusia (SDM) kesehatan dalam penanggulangan bencana. Jakarta: Departemen Kesehatan RI; 2006.

10 Musliha. Keperawatan gawat darurat. Yogyakarta. Nuha Medika; 2010.hlm.59-65. 
11 Oman KS, Kaziol-Mclain J, Scheetz LJ. Keperawatan emergency. Jakarta: ECG; 2012.hlm. 45-7.

12 Virgillio DG. Problem based learning for training health care managers developing countries. Jurnal Medical Education. 2003;3:35-47.

13 Rica M. Teori dan pengukuran pengetahuan, sikap dan perilaku manusia. Yogyakarta: Nuha Medika; 2016.hlm.75-9.

14 Nonutu. Hubungan jumlah kunjungan dengan ketepatan pelaksanaan triage di instalasi gawat darurat RSUP Prof.Dr. D Kondou Manado [tesis]. Manado: Universitas Sam Ratulangi; 2015.

15 Pohan LS. Jaminan mutu pelayanan kesehatan dasar. Jakarta: Kesaint Blanc; 2003.hlm.22-5. 